$$
\begin{aligned}
& \text { Tatay Tibor - Neumanné Virág Ildikó- } \\
& \text { Lentner Csaba - Sági Judit }
\end{aligned}
$$

\title{
Az otthonteremtési támogatási rendszer értékelése egy kérdốves vizsgálat tükrében
}

\section{Assessment of the Housing Support System in the Light of a Questionnaire Survey}

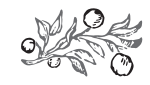

Összefoglalás

A magyar népesség demográfiai szerkezete kedvezótlen képet mutat, melynek egyik oka az alacsony gyerekvállalási hajlandóság. Tanulmányunkban bemutatjuk a gyerekvállalási ráta, a születések számának alakulását az utóbbi másfél évtizedre vonatkozóan. A kormány 2010 után a családpolitika eszközeivel kívánja a demográfiai folyamatokat kedvezóbb irányba fordítani. A családtámogatási rendszer egyik fontos eleme az otthonteremtési támogatási rendszer. A tanulmány ennek főbb összetevóit tárgyalja. Saját kérdôíves kutatást végeztünk egyetemi hallgatók körében abból a célból, hogy felmérjük, az otthonteremtési támogatási rendszernek lehet-e hatása a gyerekvállalásra, a lakáscélok várható megvalósítására. A válaszok alapján megállapítottuk, hogy

Dr. habil. Tatay Tibor PhD, egyetemi docens, Széchenyi István Egyetem (tatay@sze.hu), Neumanné Dr. Virág Ildikó PhD, egyetemi docens, Pannon Egyetem (neumanne@gtk.uni-pannon.hu), PROF. DR. LENTner CsABA CSC, egyetemi tanár, intézetvezető, Nemzeti Közszolgálati Egyetem (lentner.csaba@uni-nke.hu), DR. HABIL. SÁGi Judit PhD, fôiskolai docens, Budapesti Gazdasági Egyetem (sagi.judit@uni-bge.hu). 
Tatay Tibor - Neumanné Virág Ildikó - Lentner Csaba - Sági Judit: Az otthonteremtési...

a gyerekvállalási hajlandóságra a válaszadók szerint hatással lehet a támogatási rendszer. Lakáscéljaik eléréséhez, a megkérdezettek véleménye szerint, hozzájárulhat az otthonteremtési támogatás.

Journal of Economic Literature (JEL) kódok: I38, J13, R21, D6 , J11

Kulcsszavak: termékenységi arány, családtervezés, gyermekvállalás, családtámogatás

\section{Summary}

The demographic structure of Hungary's population is unfavourable. One of the reasons for this is the low desire to have children. The study describes developments in the birth rate and the number of childbirths in the past one and a half decades. Since 2010 the Government has used family policy instruments to reverse the demographic trend. One of the important elements of the family support system is the housing subsidy scheme. This paper gives an overview of its main components. We conducted our questionnaire research among university students in order to assess whether the housing support system could have an impact on both the willingness to have children and the expected implementation of housing objectives. Based on the answers it was found that the support system can actually influence the respondents' plans to have children. Respondents believe that the housing subsidy scheme may help them achieve their home-making objectives.

Journal of Economic Literature (JEL) codes: I38, J13, R21, D6 , J11

Keywords: fertility rate, family planning, childbearing, family subsidies

\section{BEVEZETó}

Az utóbbi évtizedekben a magyarországi demográfiai helyzet kedvezótlen képet mutat. A társadalom korösszetételének egészséges volta a fenntartható fejlódés alapja. A kedvezôtlen demográfiai folyamatok a társadalom, a gazdaság minden területére hatással vannak. Az európai országok többségének, benne Magyarországnak, égetô gondja a társadalom elöregedése. 2010 után a kormányzat középpontba állította a családok helyzetének javítását, a gyermekvállalás támogatását. A megvalósuló programok egyik kiemelt pillére az otthonteremtési támogatási rendszer.

Kérdôíves kutatást végeztünk egyetemisták körében, arra keresve a választ, hogy a 2016-ban kiszélesített otthonteremtési támogatási rendszer várhatóan emelheti-e a gyermekvállalási kedvet. Arra kerestük a választ, hogy látják a fiatalok, várhatóan segíti-e lakáscéljaik elérését a támogatási rendszer. Kutatásunk mintavétele miatt a kapott eredmények nem reprezentálják a szülőképes lakosság véleményét, de egyfajta gyorsképet adnak a bevezetett támogatások fogadtatásáról, lehetséges hatásáról. 


\section{A SZÜletésSZÁM ALAKULÁSA MAgYARORSZÁGON}

Hazánkban a teljes termékenységi arányszám a rendszerváltást követôen 1,3 körüli szintre csökkent, és a 2000-es évek elején ezen a szinten stagnált. Ezt a helyzetet még súlyosbítja, hogy 2016-ban már minden hatodik - magyar szülóktól származó - gyermek külföldön született. A születések számát nézve igen kedvezôtlen irányt mutatnak az értékek.

\section{1. ábra: Az élveszületések számának alakulása Magyarországon 2000 és 2015 között}

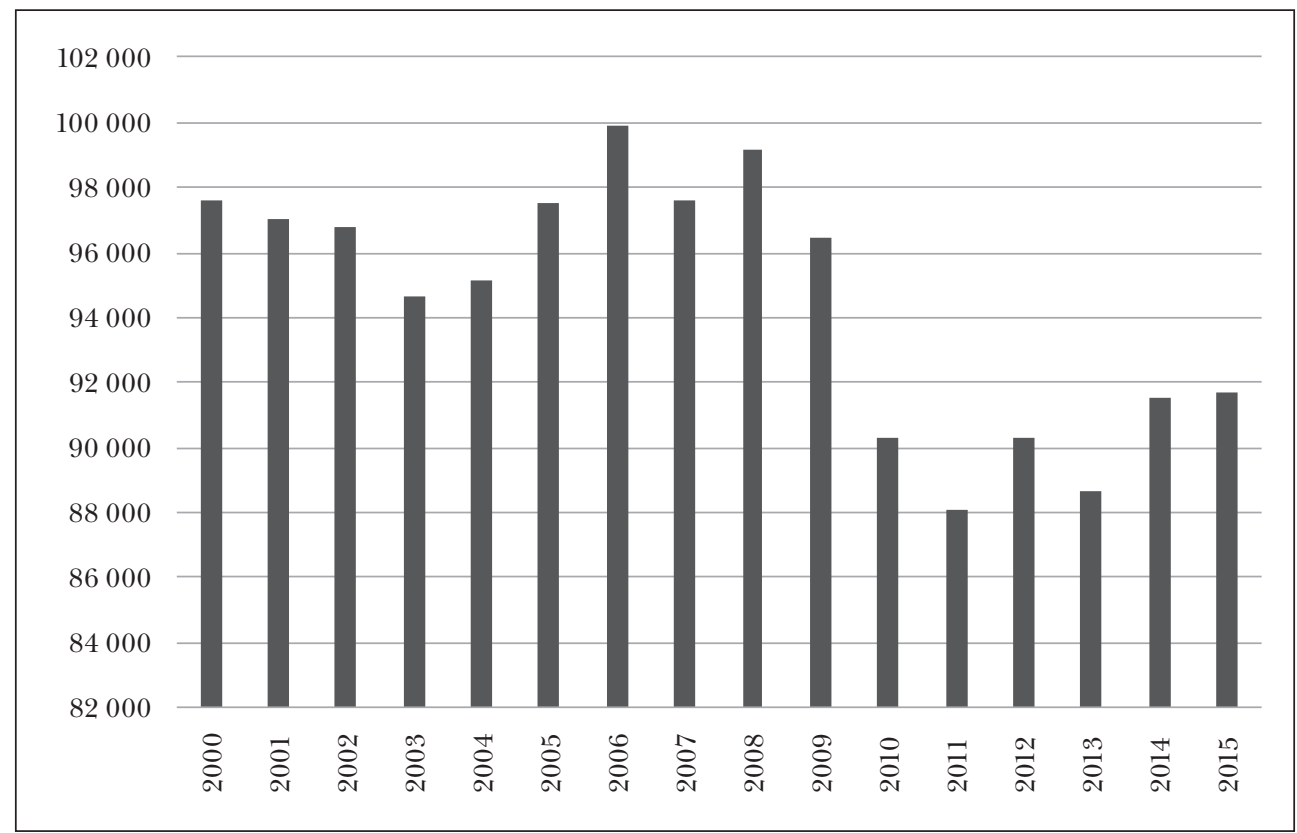

Forrás: Saját szerkesztés a KSH adatai alapján

A születések száma a rendszerváltás utáni elsô évtized végére csökkent hozzávetôleg 95 000-re, majd 2000 és 2008 között a 95000 és 100000 közötti szinten stagnált. 2008-tól 2010-re jelentôs további csökkenés történt, a születésszám 90000 körüli szintre esett, 1994-ben és 2015-ben 91500 körül alakult. Az elkövetkezó években a szülőképes korosztályokba tartozó nôk száma csökken, így a gyermekvállalási hajlandóság növekedése mellett is alacsonyabb lehet a születések száma (Kapitány-Spéder, 2015).

A rendszerváltozás után megfigyelhetô tendencia, hogy a nôk a gyermekvállalást egyre késóbbi korra halasztják, ami az alacsony magyar termékenységi arány magyarázó tényezői közt szerepel. A halasztás mögötti okként elsôsorban az iskolában töltött idő meghosszabbodása áll. Ugyanakkor a fiatalok hangsúlyos tényezőnek tartják a gyermekvállaláshoz a megfelelő gazdasági háttér, azaz a munkahely meglétét, illetve a 
lakáshelyzetük megoldását. A stabil lakáshelyzet alapvetóen a saját lakás megszerzését takarja (Bálint et al., 2011).

A gyermekvállalási hajlandóság csökkenésének okaiként Spéder (2014) megfogalmazza, hogy a rendszerváltás után a társadalmi szerkezetben, az intézményrendszerben bekövetkezô változások kedvezótlen közeget teremtettek. Tanulmányában hivatkozik arra, hogy a munkaerôpiaci bizonytalanságok, a változó családtámogatási rendszer szintén visszavetették a gyermekvállalási hajlandóságot.

A szociológusok és demográfusok szerint a gyermekvállalási hajlandóság csökkenése mögött az európai országokban és Magyarországon is komplex társadalmi folyamatok állnak. A hagyományos létformák felbomlása, a fogyasztói társadalmakban az egyének családot érintő felfogásának átalakulása olyan minőségi változások, amelyek születésszámokra gyakorolt hatását nehéz számszerúsíteni. Ezeket a mélyen a kultúrában gyökerező okokat várhatóan nehéz megváltoztatni, gazdasági eszközökkel korlátozottan befolyásolhatók.

A gyermekvállalási hajlandóság mögött azonban gazdasági tényezók is jelen vannak. A stabil gazdasági háttér elemei között a saját lakás megléte fontos összetevô. A lakástulajdon megszerzésének ideje befolyásolja a gyermekvállalás idôpontját: az elsố lakás korábbi megszerzése az elsô gyermek vállalásának korábbra hozatalát eredményezheti. A késóbbiekben a nagyobb lakás megszerzésének lehetôsége szintén a további gyermekek vállalását segítheti.

\section{AZ OTTHONTEREMTÉSI TÁMOGATÁSI RENDSZER ÉS A CSALÁDPOLITIKA}

A hazai közgazdasági gondolkodásban felerôsödtek a gyermekvállalás gazdaságpolitikai eszközökkel történô segítésére irányuló szándékok (Giday, 2011; 2012). Mindez a magyar családpolitikában már tükrözôdik: az állam a családpolitikájában határozza meg a gyermekvállalás ösztönzését, a gyereknevelés segítését. A családpolitika szúkebb értelmezésben felfogható a gyerekeket nevelố családokat támogató állami juttatások és szolgáltatások összességeként. A családtámogatási rendszer azokat a szociálpolitikai eszközöket foglalja magában, amelyek a gyerekek nevelésében a társadalom közös felelôsségét fejezik ki. A gyerekneveléshez való közösségi hozzájárulás az állami újraelosztó rendszeren keresztül valósul meg (Darvas-Mózer, 2004).

A magyar kormányzat 2010 után újrafogalmazta családpolitikáját, családtámogatási rendszerét. Ennek fontos sarokköve az otthonteremtési támogatási rendszer. A szociálisabb ihletésú támogatási rendszert újraélesztve 2012-től indult az Otthonteremtési Program. Ennek egyik eleme a megújuló szociálpolitikai támogatás lett, célja a lakással még nem rendelkezôk lakásépítésének és lakásvásárlásának támogatása. A másik elem az otthonteremtési kamattámogatás volt, melynek rendeltetése kamattámogatott hitelek nyújtása, amely új lakás vásárlására, építésére, használt lakás vásárlására, lakás korszerúsítésére volt felhasználható. Másodlagosan ez a forma a bajba jutott adósok segítését is célozta. Az otthonteremtési kamattámogatás felhasználható lett késedelmes jelzáloghitellel vagy felmondott kölcsönnel terhelt 
lakóingatlan vásárlásához, valamint hátralékos hiteladós által kisebb lakás vásárlásához (NGM, 2012).

A magyar gazdaság teljesítményének javulása és a költségvetés stabilizálódása 2015ben lehetôvé tette a támogatási rendszer továbbfejlesztését, így a vissza nem térítendô támogatás körét kiterjesztették a használt lakások vásárlására is. Továbbra is rendelkezésre áll a kamattámogatott hitel igénybevételének lehetôsége lakás építésekor, illetve vásárlásakor; ezenfelül további kedvezményt jelent az adó-visszaigénylés. A kedvezmények már kiterjednek az egy gyermekkel rendelkezókre, vagy az egy gyermeket vállalókra is. A vissza nem térítendô családtámogatási kedvezmény (csok) és a kamattámogatott hitel maximálisan megkapható összege emelkedett. 2015 júliusától a családok otthonteremtési kedvezménye használt lakás vásárlására és új lakás építésére és vásárlására is felhasználhatóvá vált, összege a jogosultsági feltételek alapján 500000 és 3250000 forint között változott.

2016 elejétôl a támogatási összegek emelkedtek, ugyanakkor a használt lakások vásárlására és az új lakás vásárlására vagy építésére megkapható összegek már jelentôs eltérést mutattak. Egyértelmúen kifejeződött, hogy a kormány az új lakások építését részesíti elônyben. 2016. január 1. után az egy gyerek után igényelhetố családi otthonteremtési kedvezmény 600 000, két gyerek után 2600000 forint, három vagy több gyerek után maximálisan tízmillió forint lett. A vissza nem térítendô támogatás mellett tízmillió forint kamattámogatott hitel felvételére is megteremtették a lehetôséget, és az új lakást építôk ötmillió forint általános forgalmi adó visszaigénylésére is jogosulttá váltak.

A 2016 elejétól életbe lépett változások, majd a 2016-ban több lépcsôben megtörtént módosítások a támogatási rendszer igénybevételi feltételeinek további finomhangolását célozták. A módosítások alapvetô vonása volt, hogy az igénybevétel feltételeit kedvezôbbé tegyék, a támogatási rendszer lehetôségeivel a gyereket neveló és vállaló családok minél szélesebb körben élhessenek. Ilyen változtatások voltak például a szülók korára, a megvásárolni kívánt lakások négyzetméterárára, a lakásnagyságra vonatkozó változtatások (Csalad.hu, 2017).

\section{A KÉRDÔÍVES KUTATÁS EREDMÉNYEI}

Kérdôívünk húsz kérdésból állt. A megkérdezés 2016 novembere folyamán zajlott le, 1332 fôvel. A kérdốiv kitöltésében nappali és levelezô tagozatos budapesti és gyôri egyetemi hallgatók vettek részt. A vizsgálati körben lévook azok közé tartoztak, akik elvileg már termékeny életkorban vannak, illetve a napjainkban szokásos gyermekvállalási életkort pár év múlva már elérik, vagy éppen jelenleg már ebbe a korba jutottak.

A kérdőív elsố részében, az 1-6. kérdésben a válaszadók nemére, korára, lakhelyére, testvéreinek számára és lakáshelyzetére kérdeztünk rá, illetve munkatapasztalataikra voltunk kíváncsiak, hogy néhány alapvetô demográfiai jellemzôt megismerjünk. A válaszok alapján a megkérdezettek 42,6\%-a férfi, 57,4\%-a nô. A válaszadókból 18 és 25 év közötti 735 volt, ami 55,2\%-ot jelent. 22,4\% a 26-30 éves korcsoportba tartozott, a 31 és 35 év közöttiek 11,4\%-ot tettek ki, míg a 35 felettiek 11\%-ot. 
Tatay Tibor - Neumanné Virág Ildikó - Lentner Csaba - Sági Judit: Az otthonteremtési...

A kitöltők 2,2\%-a 500 lakosnál kisebb településen lakik, 7,5\%-uk 500-1000 lakosú településen, míg 26,3\%-uk 1000-10 000 lakosú településen él. A 10 000-500 000 lakosú településeken 28,5\%-ban élnek, a válaszadók 35,5\%-a lakik Budapesten.

A megkérdezettek 15,4\%-a nem rendelkezik testvérrel, 47,9\%-uk egy testvérrel, két testvérrel 24,9\%-uk, három testvérrel pedig 7,6\%-uk rendelkezik, és mindössze 4,2\%-uknak van háromnál több testvére.

A válaszadók 56,3\%-a saját családi házban lakik, 10,3\%-uk 2-4 lakásos társasházban levô saját lakásban, 13,6\%-uk 5-16 lakásos társasházban levố saját lakásban, 13,4\%-uk pedig 16-nál több lakásos társasházban levő saját lakásban. A fennmaradó 6,4\% szolgálati vagy bérlakásban él.

A megkérdezettek 29,2\%-a nyári diákmunka során szerzett munkatapasztalatot. 28,9\%-uk egy-három éves tapasztalattal rendelkezik, négy-hat éves munkatapasztalata pedig 12,8\%-nak van. A fennmaradó $29,1 \%$ több mint hatéves munkatapasztalattal rendelkezik.

Az ezt követô kérdések arra irányultak, hogy megtudjuk, a megkérdezettek igénybe vesznek-e pénzügyi termékeket, illetve mennyire rendelkeznek pénzügyi ismeretekkel. A vonatkozó kérdések az alábbiak voltak:

7. Használ-e bankkártyát?

8. Használ-e internetbanki szolgáltatásokat?

9. Van-e családjának lakására jelzálogterhelés bejegyezve?

10. Tételezzük fel, hogy hosszú lejáratú hitelt vesz fel, ahol a havi törlesztôrészletek (tôketörlesztés + kamat) a teljes futamidố alatt mindig állandók. Egyik bank 6\%-os kamatláb mellett tízéves futamidôre, a másik bank 6\%-os kamatláb mellett húszéves futamidőre kínálja hitelét. Melyik futamidőnél lenne magasabb az elsô hónapban fizetendő kamat összege?

11. Ismeretei szerint mely hitelfajta kamata a legalacsonyabb jelenleg a hazai piacon?

A válaszadók 29,6\%-a legfeljebb havonta használja a bankkártyát, heti rendszerességgel 31,8\%-uk, a válaszadók 34,2\%-a napi szinten használja a kártyáját. A kérdóív kitöltői közül 18,2\%-a egyáltalán nem használ internetbanki szolgáltatásokat, míg 44,2\%-a legfeljebb havonta használja. A válaszadók 29,8\%-a hetente, a fennmaradó $7,8 \%$ pedig napi rendszerességgel használja.

A válaszadók 22,4\%-ának van a családban jelzálogterhelése, 67,8\%-a azonban nem rendelkezik jelzáloggal. A maradék 9,8\%-a nem tud róla. 35,2\% tudott csak helyes választ adni arra, hogy azonos kamatozási feltételek mellett, ugyanakkora összegú hitelnél, eltérô futamidő esetén hogy viszonyul a különbözô konstrukciók kamata egymáshoz az első hónapban.

A 11. kérdésre, hogy mely hitel kamatlába a legalacsonyabb aktuálisan a piacon, a válaszadók 45,8\%-a adott helyes választ.

A megkérdezettek túlnyomó része tehát nem használ napi rendszerességgel bankkártyát, még kevésbé jellemzô a napi internetes bankolás. Jelzáloghitellel csak mintegy ötöde rendelkezett a kérdezésbe bevontak családjaiból. (Ez viszonylag kicsi arány, még akkor is, ha idesorolnánk azokat is, akik nem tudták a választ.) Ennek fényében talán 
nem annyira meglepő, hogy nem ismerik a különböző hitelek kamatlábait, hiszen kérdésünkre 50\%-nál kevesebben válaszoltak helyesen. Az ismeretekre vonatkozóan elgondolkodtató, hogy a válaszadók egyharmada tudja csak a konkrét hitelszámítás helyes eredményét. (Talán ez annak tudható be, hogy a kérdésre intuitív választ adtak.)

A 12-15. kérdések arra irányultak, hogy felmérjük, mennyire ismerik a megkérdezettek a családtámogatási rendszer elemeit.

12. Ön szerint mekkora vissza nem térítendô támogatás jár a családi otthonteremtési kedvezmény keretén belül két vállalt gyermek után, új lakás vásárlása esetén?

13. Az Ön tudomása szerint kik vehetik igénybe a családi otthonteremtési kedvezményt?

14. Ismeretei szerint az otthonteremtési kamattámogatás igénylése mely esetben lehetséges?

15. Ismeretei szerint melyik az igaz az alábbiakból új lakás építése esetén?

A kitöltók közül a 12-es kérdésre 58,8\% adott helyes választ, azaz ismerte, mekkora a lehetséges támogatás összege két gyerek után. A 13-as kérdésre a válaszadók 50,2\% válaszolt helyesen, azaz tudta, hogy az otthonteremtési kedvezmény lehetséges igénybe vevôi lehetnek a házastársak és az élettársak is. A 14-es kérdés vonatkozásában a megkérdezettek 54,1\%-a ismerte, mikor kapható az otthonteremtési kamattámogatás. A 15. kérdésre a megkérdezettek közül azok 47,6\%-a ismerte a jó választ a családi otthonteremtési kedvezmény és az általános forgalmi adó együttes igénylése vonatkozásában.

A kérdésekre adott válaszok alapján az állapítható meg, hogy a megkérdezettek mintegy fele az otthonteremtési támogatási rendszert ismeri, szabályaival tisztában van.

A 16. és 17. kérdés azt célozta, hogy megtudjuk, a családtámogatási rendszer tükrében a megkérdezettek miként vélekednek a gyermekvállalási kedv változásáról.

16. Ön szerint a gyermekvállalási kedvet növelik-e az újonnan bevezetett lakástámogatási intézkedések?

17. Várhatóan Ön gondolkodik-e az eddig tervezettnél több gyermek vállalásában a jelenleg bevezetett lakástámogatási rendszer fennmaradása esetén?

Mivel magának a megújított és kibóvített családtámogatási rendszernek a lényege, hogy a gyermekvállalást ösztönözze, így a teljes megkérdezetti körre és ezek csoportjaira lebontva is értékeltük a válaszokat. Fontos kérdés volt számunkra, hogy megismerjük, „általában” hogy gondolkodnak a megkérdezettek az otthonteremtési támogatás gyermekvállalást ösztönzô hatásáról. A válaszok a megkérdezettek teljes körében, illetve ezek csoportjaiban a következôk voltak: a kitöltôk 15,4\%-a szerint a támogatás jelentősen növeli a gyermekvállalási kedvet, 58\% szerint növeli ugyan, de nem lényegesen, 19,2\% szerint egyáltalán nem befolyásolja, 7,4\% pedig nem tudja megítélni ezt a kérdést.

A férfiak és nók megítélése ennél a kérdésnél majdnem azonos volt. A válaszadó férfiak 15,1\%-a szerint a bevezetett kedvezmények nagymértékben, 57\%-uk szerint nem lényegesen növelik meg a gyermekvállalási kedvet, 19,5\% férfi szerint egyáltalán nem növelik a gyermekvállalási kedvet az újonnan bevezetett lakástámogatási intéz- 
Tatay Tỉbor - Neumanné Virág Ildikó - Lentner Csaba - Sági Judit: Az otthonteremtési...

kedések. A nốk hasonlóan válaszoltak, míg 15,6\%-a szerint jelentôs mértékben megnövelik a gyermekvállalási kedvet az újonnan bevezetett kedvezmények, addig 58,9\% szerint csak csekély mértékben (3. ábra).

2. ábra: A 16. kérdésre adott válaszok megoszlása

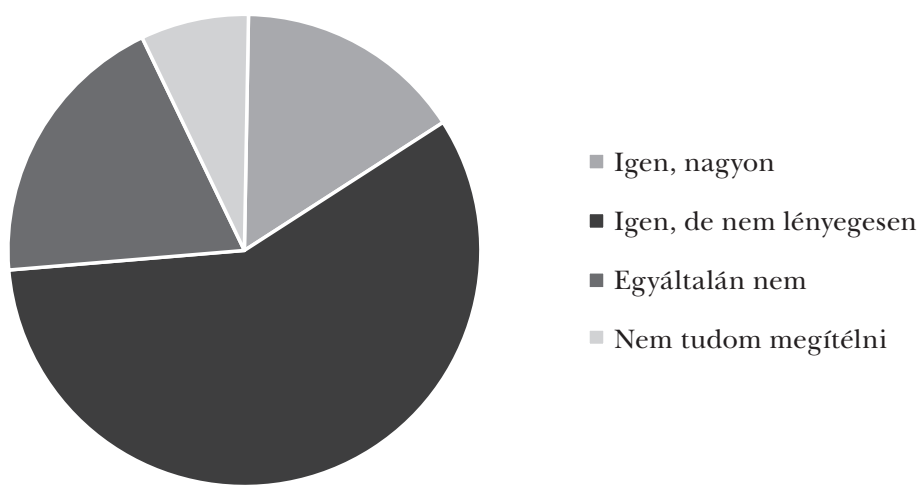

Forrás: Saját kérdốiv

3. ábra: A 16. kérdésre adott válaszok megoszlása az egyes nemeknél

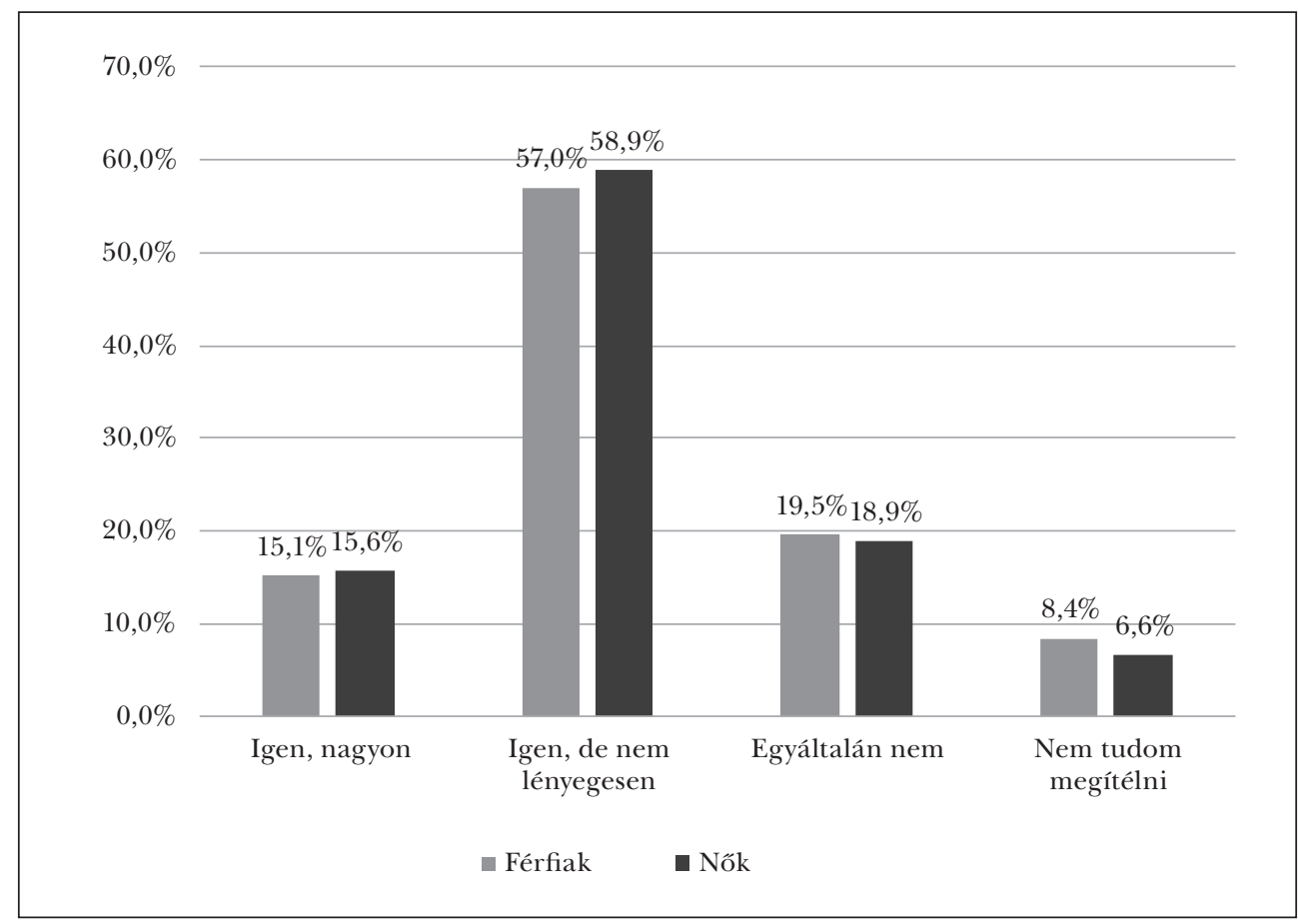

Forrás: Saját kérdốv 
Korcsoportok szerint vizsgálva a válaszokat sem tapasztaltunk nagy eltérést. A 1825 éves korosztályból 16,9\% válaszolta azt, hogy a lakástámogatás erôsen hatással van a gyermekvállalásra. $59 \%$ pedig azt, hogy hatással van ugyan, de nem lényeges módon. A 26 és 30 év közöttiek 17,4\%-a nagyon számottevőnek, 59,5\%-a számottevőnek, de nem lényegesen számottevônek gondolja a hatást, 15,4\% egyáltalán nem véli hatásosnak a támogatást a gyermekvállalás növelésére. A 31 és 35 év közöttieknél 9,3\% ítéli hatásosnak a támogatást, míg 30,5\% nem tulajdonít hatást a gyermekvállalásra. A 35 év fölöttiek esetén 10,4\% nagyon hatásosnak véli a támogatást (4. ábra).

\section{4. ábra: A 16. kérdésre adott válaszok megoszlása az egyes korcsoportoknál}

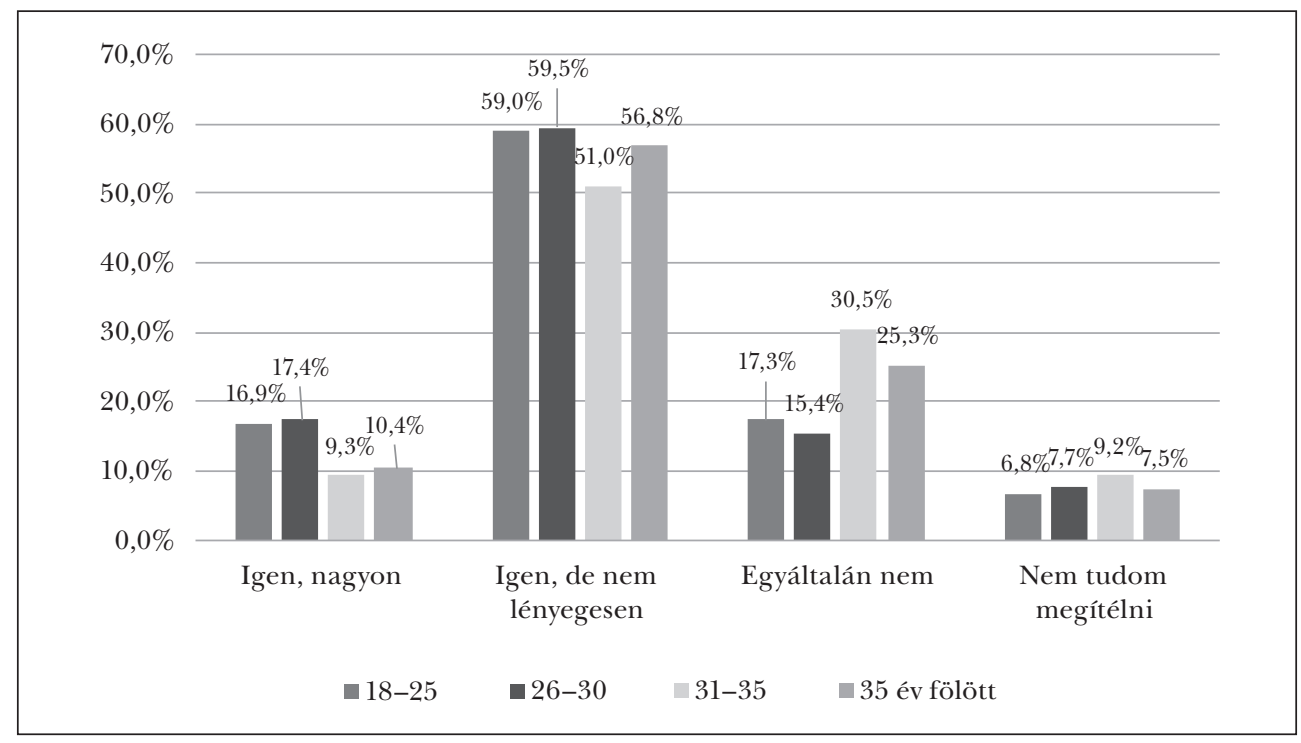

Forrás: Saját kérdôiv

A testvérek száma szerint bontva a válaszadókat a kérdésre, akiknek nincs testvérük, 18,7\%-ban erôsnek érzik a hatást, 48,8\%-uk igennel válaszolt ugyan, de nem tartják lényegesnek a kifejtett hatást. 23,6\%-uk szerint egyáltalán nem” befolyásolja a gyermekvállalási kedvet a támogatás. Akiknek van testvérük, nagyobb arányban tulajdonítottak jelentőséget a támogatás bevezetésének. Az egy testvérrel rendelkezôk 14,3\%-a nagyon hatásosnak véli a támogatást, 61,9\%-a nem lényeges hatásúnak, a két testvérrel rendelkezők 15,2\%-a nagyon hatásosnak gondolja, míg 59,1\%-a hatásosnak véli, de nem nagyon. A három vagy annál több testvérrel rendelkezók 15,2\%-ban, illetve 12,7\%-ban nagy hatást tulajdonítanak a támogatásnak (5. ábra).

A 17. kérdésben meg kívántuk tudni, hogy a válaszadók magukra vonatkoztatottan ösztönzônek gondolják-e a gyermekvállalással kapcsolatban az otthonteremtés támogatását. A válaszok a következô módon oszlottak meg: a válaszadók 8,2\%-a több gyermek vállalásában gondolkozik a bevezetett támogatás hatására, 28,5\% szerint lehetséges, hogy ez befolyásolja a késóbbiekben a gyermekeik számát, 53,5\% szerint 
Tatay Tỉbor - Neumanné Virág Ildikó - Lentner Csaba - Sági Judit: Az otthonteremtési...

azonban egyáltalán nem befolyásolja. A kitöltôk 9,8\%-a nem tudja megítélni a támogatás hatását.

5. ábra: A 16. kérdésre adott válaszok megoszlása a testvérek száma szerinti megbontásnál

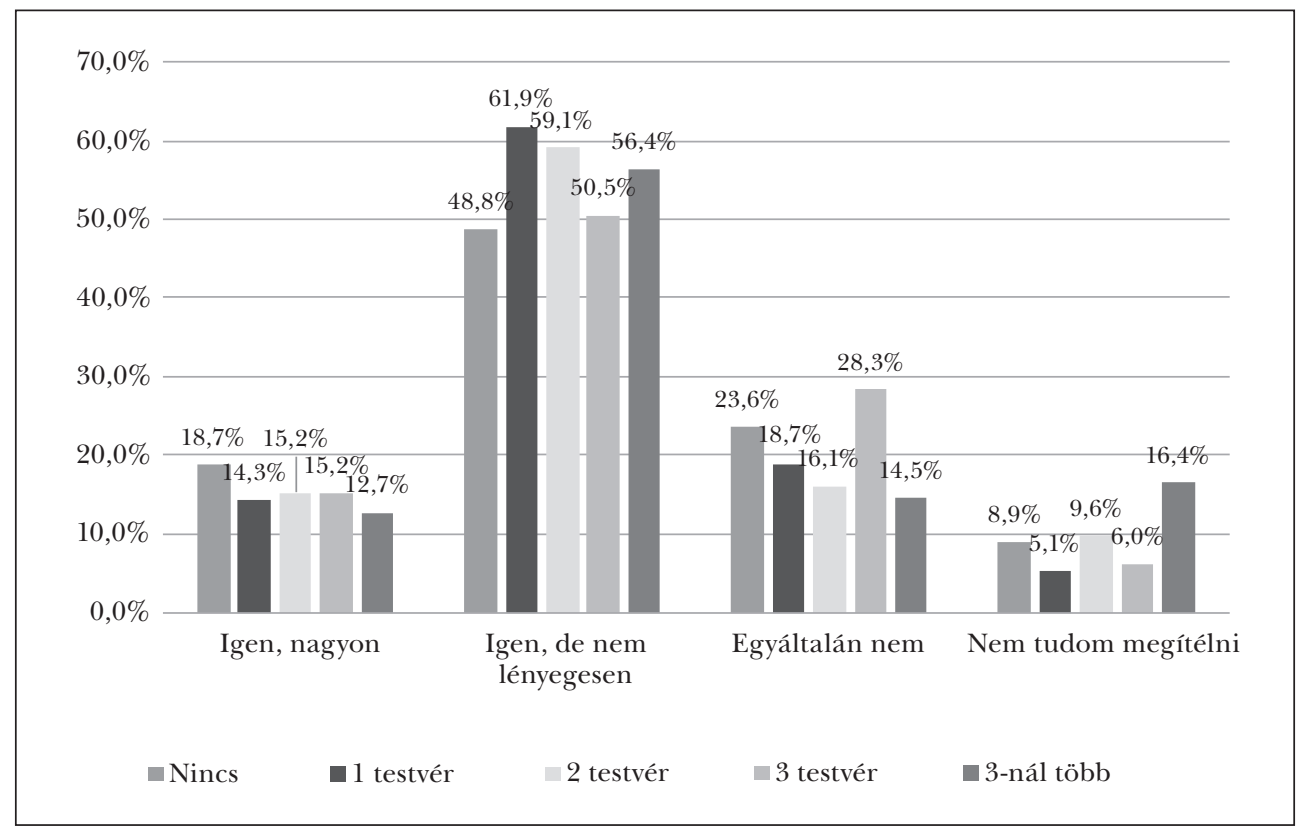

Forrás: Saját kérdốiv

6. ábra: A 17. kérdésre adott válaszok megoszlása

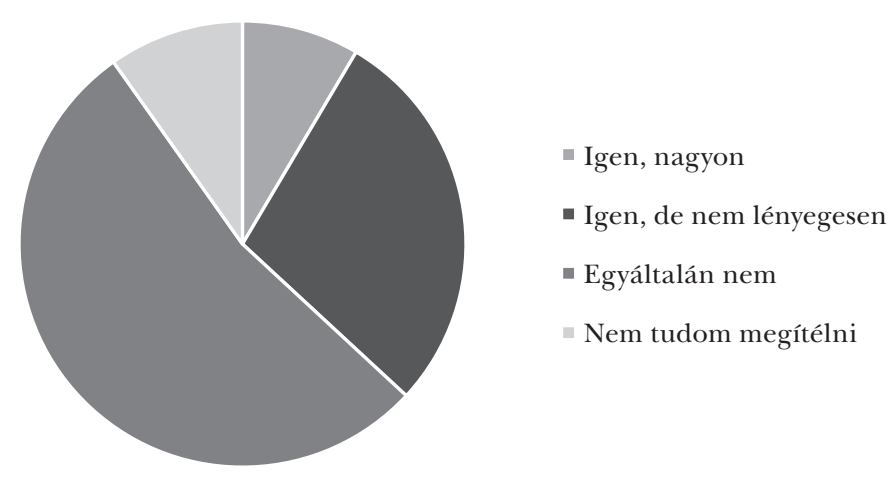

Forrás: Saját kérdôív

Nemek szerint vizsgálva a válaszokat, nem találtunk számottevố eltérést a csoportok között. Az újonnan bevezetett lakástámogatási rendszer hatására a férfi válaszadók 9,7\%-a gondolkodik a tervezettnél több gyermek vállalásában, míg 46\%-uk nem, illetve 31,6\%- 
uk elképzelhetônek tartja a lehetséges hatást a gyerekek számára vonatkozóan. A férfiak 12,7\%-a nem tudja megítélni az adott kérdést. A nôi válaszadók körében 7,1\% úgy gondolja, hogy biztosan befolyásolják a vállalandó gyerekek számát az új intézkedések, 26,1\% nói válaszadó véli lehetségesnek, hogy kihatással van a helyzetre az új lakástámogatási rendszer. 59,1\% szerint egyáltalán nem lesz hatással a gyerekek számára az újonnan bevezetett kedvezmény, és 7,7\% nôi válaszadó nem tudja megítélni a kérdést (7. ábra).

\section{7. ábra: A 17. kérdésre adott válaszok megoszlása az egyes nemeknél}

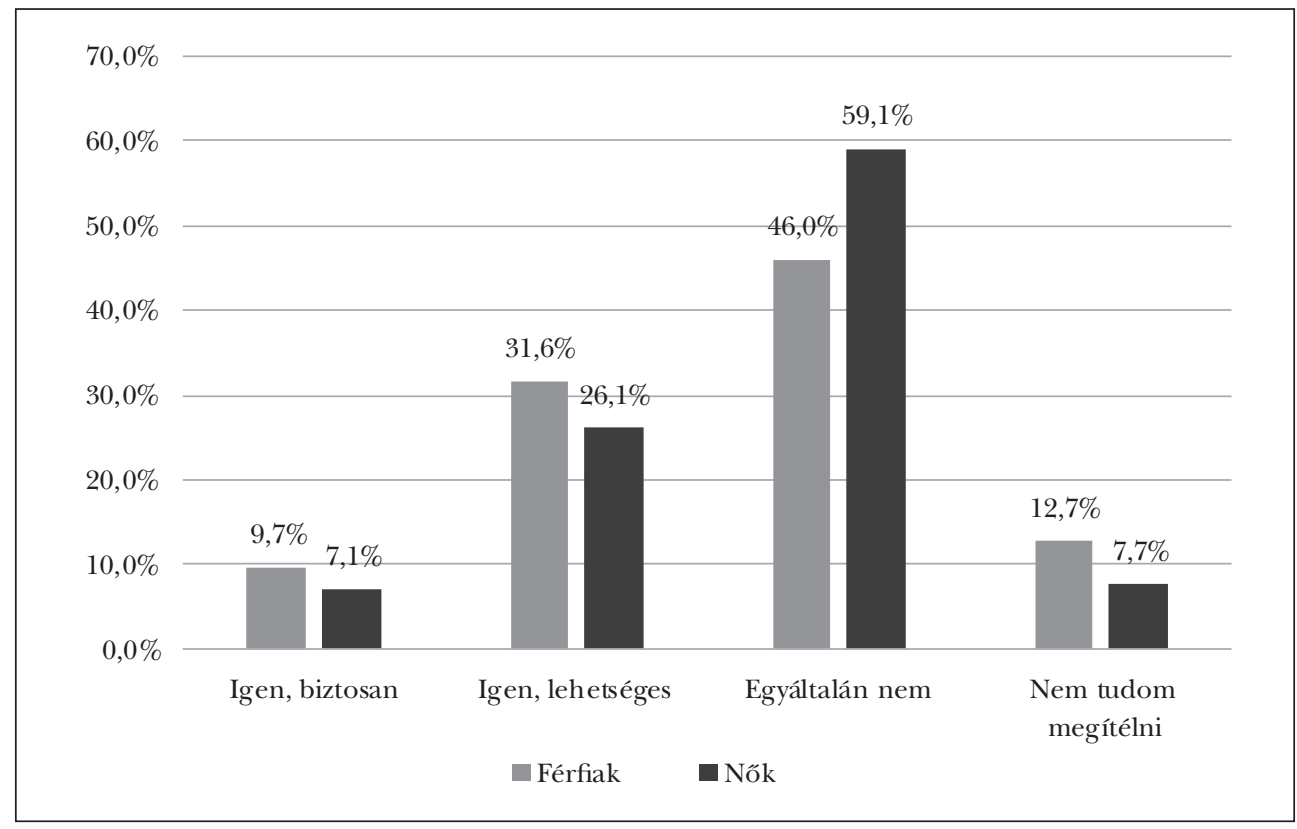

Forrás: Saját kérdốv

Kor szerint csoportosítva a válaszadókat, a válaszok megoszlása a következóképpen alakult: a 18-25 éves korosztályból 9,2\% válaszolta azt, hogy „Igen, biztosan”, 51,5\% viszont egyáltalán nem gondolkodik több gyerek vállalásában a támogatás hatására. A 26 és 30 év közöttiek közül 8,4\% vállalna több gyermeket, 35,3 lehetségesnek tartja. A 31 és 35 év közöttiek 8,6\%-a biztosan több gyereket vállalna, 28,5\% lehetségesnek tartja a több gyerek vállalását, $53 \%$ nem vállalna több gyereket. Végül a 35 év fölöttiek 2,7\%-a biztosan vállalna több gyereket, $69,9 \%$ viszont egyáltalán nem tartja lehetségesnek a több gyereket (8. ábra).

A testvéreik száma alapján bontva a válaszadókat, a gyermekvállalási hajlandóságra azok közül, akiknek nincs testvérük, 24,6\%-ban lehetségesnek tartják a több gyermek vállalását, 55,2\%-uk viszont egyáltalán nem. A három testvérrel rendelkezók tartják leginkább elképzelhetônek, hogy a támogatás hatására több gyermeket vállaljanak, az egy testvérrel rendelkezők gondolták úgy legmagasabb arányban, hogy egyáltalán nem vállalnának több gyermeket a támogatás hatására (9. ábra). 
Tatay Tỉbor - Neumanné Virág Ildikó - Lentner Csaba - Sági Judit: Az otthonteremtési...

8. ábra: A 17. kérdésre adott válaszok megoszlása az egyes korcsoportoknál

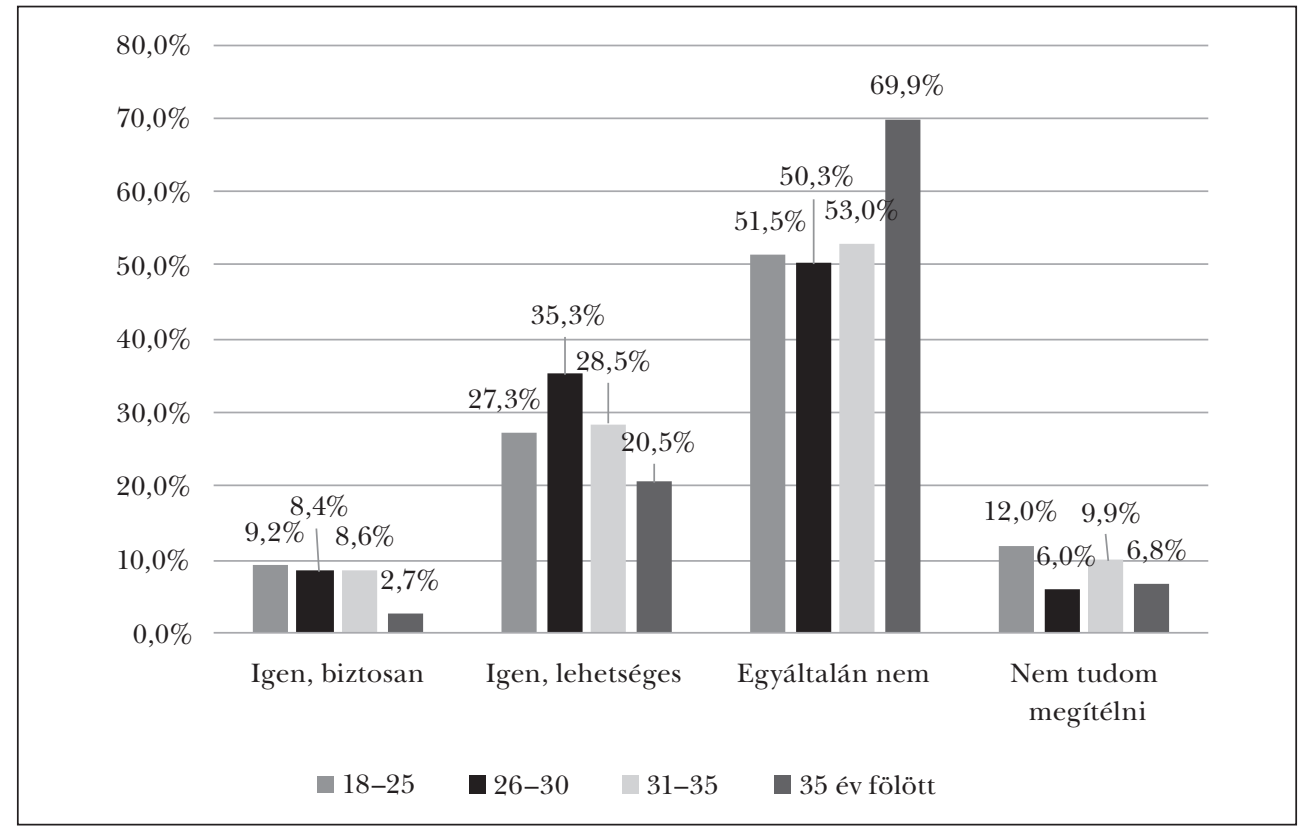

Forrás: Saját kérdốv

9. ábra: A 17. kérdésre adott válaszok megoszlása a testvérek száma szerinti megbontásnál

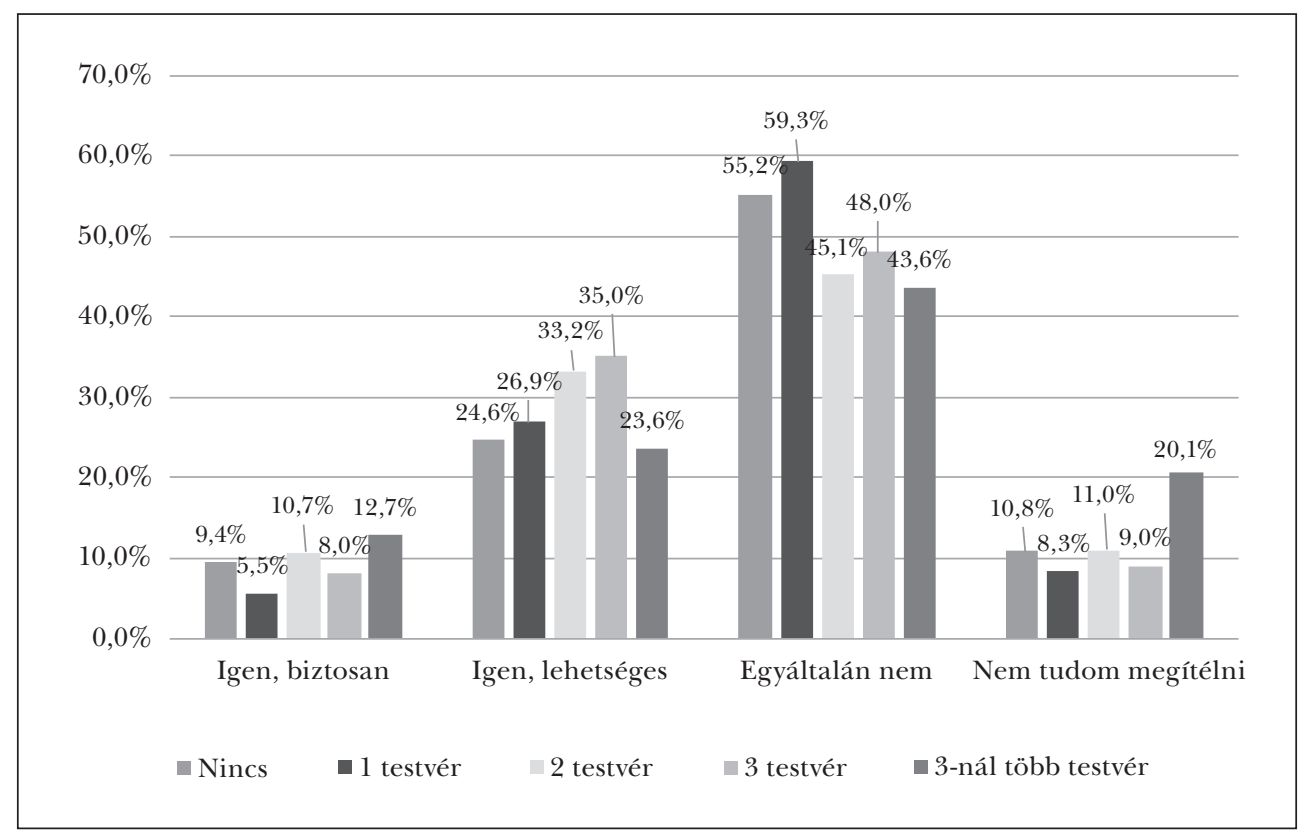

Forrás: Saját kérdốiv 
A 18. és 19. kérdés arra irányult, hogy megtudjuk, a családtámogatási kedvezmény feltételrendszerének teljesíthetôségét kockázatosnak látják-e a megkérdezettek, illetve saját lakásigényeik teljesülése vonatkozásában mit gondolnak a kapható támogatásokról.

18. Ön szerint a jelenleg bevezetett lakástámogatási rendszer feltételeinek betartása nagy kockázatot jelent az igénybe vevôknek?

19. Az Ön által elvárt lakás megszerzéséhez, illetve kialakításához milyen mértékben járulhat hozzá - fennmaradása esetén - a jelenleg bevezetett lakástámogatási rendszer?

A 18-as kérdésre adott válaszok alapján a megkérdezettek 22,2\%-a szerint nagymértékú kockázatot jelent az igénybe vevôk számára a rendszer által szabott feltételek betartása. 30,6\% szerint csak kismértékú kockázatot jelent, 27,6\% szerint a legtöbb igénybe vevő számára betarthatók a meghatározott feltételek. 5,4\% úgy látja, hogy egyáltalán nem kockázatosak a feltételek, míg a fennmaradó 14,2\% nem tudja megítélni a helyzetet. A válaszok azt mutatják, hogy a válaszadók mintegy fele kisebb-nagyobb kockázatokat lát a támogatások feltételeinek teljesíthetôségénél.

A 19. kérdéssel meg kívántuk tudni, hogy a megkérdezettek hogyan látják a támogatási rendszer lakáshelyzetükre vonatkozó befolyását. A kérdőívet kitöltôk közül 20,1\% úgy gondolja, hogy a támogatás jelentôsen hozzájárulhat az előre kigondolt lakás megvásárlásához, 41,9\% szerint a hozzájárulás csak kismértékú lehet, míg 37,5\% szerint egyáltalán nem lesz hatással a támogatás mértéke a lakás megvásárlásához, illetve kialakításához, 0,5\% nem tudja a kérdést megítélni.

Következtetésünk az, hogy a válaszadók a támogatási rendszert általában pozitívan értékelik a saját jövóbeli lakásvásárlásuk szempontjából. Több mint 60\%-ban vélik úgy, hogy az otthonteremtési támogatás várhatóan segít az elképzelt lakás megszerzésében.

Az utolsó, 20. kérdésünkben arra kérdeztünk rá, hogy a válaszadók milyen forrásból számítanak megbízható információra a családtámogatásokról.

20. Megítélése szerint honnan szerezheti a legpontosabb információkat a jelenleg bevezetett lakástámogatási rendszer feltételeirôl?

A válaszadók 32,8\%-a szerint az Emberi Erôforrások Minisztériumának ügyfélszolgálatától szerezhetố a legpontosabb információ a támogatással kapcsolatosan. 52,4\% szerint a bankok ügyfélszolgálataitól, míg 6,9\% szerint ismerôsöktôl szerezhetô be a legpontosabb információ. A megkérdezettek 7,9\%-a azonban nem tudja megítélni a helyzetet.

\section{A KAPOTT EREDMÉNYEK ÉRTÉKELÉSE}

Az egyetemisták körében végzett kérdőíves vizsgálatunk alapján az látható, hogy az otthonteremtési támogatás befolyást gyakorol a családalapítási terveikre. Gondolkodásukban jelenleg ugyan elsôsorban az mutatható ki, hogy másokról feltételezik a gyermekvállalási kedv növekedését. Ez azonban arra utal, hogy a beállítódások változását feltételezik, ami a saját gondolkodásukra is visszahathat, illetve mérhetôen hat is. Az empirikus kutatás keretében megállapítottuk, hogy a gyermekvállalási korba érô fiatalok szándékait előreláthatóan megváltoztatja a támogatási rendszer megléte. Saját 
kérdőíves vizsgálatunkban 1332 felsôoktatásban tanuló hallgató vett részt. A válaszadók 73,4\%-a szerint a gyermekvállalási kedvet növeli az otthonteremtési támogatás. $36,7 \%$ válaszolta azt, hogy a támogatási rendszer fennmaradása esetén maga is vállalna több gyereket.

Ugyanakkor a feltételrendszerben rejlô kockázatokat érzékelték a megkérdezettek. A válaszadók 22,2\%-a szerint nagymértékú kockázatot jelent az igénybe vevôk számára a rendszer által szabott feltételek betartása, 30,6\% szerint pedig kismértékú kockázatot jelent. A kockázatok érzékelése kihathat a gyermekvállalásra. Igaz, a kockázatokat ellentételezheti, hogy a kívánt lakáscélok könnyebben megvalósíthatók. A válaszadók mintegy kétharmada szerint a támogatási rendszer hozzájárulhat lakáscéljaik eléréséhez.

A kérdôív adatai alapján meg kívántuk állapítani, hogy a válaszadók között kialakíthatók-e csoportok. Például esetlegesen a gyakoribb bankkártyahasználók jobban ismerik a támogatási rendszer feltételeit, vagy a több testvérrel rendelkezôk gyermekvállalását jobban ösztönzi-e a támogatás. A kapcsolatok keresésében alkalmazott statisztikai módszerek a kereszttábla-elemzés, továbbá a khí-négyzet-próba voltak. Vizsgálataink eredményei szerint az elemzett változók közt sem a kereszttábla-elemzés, sem a khínégyzet-próba alapján nem voltak szignifikáns összefüggések megállapíthatók.

\section{FELHASZNÁLT IRODALOM}

Bálint Lajos et al. (2011): Demográfiai jövókép. Magyarország demográfiai jövôjét meghatározó tényezốk alakulásának áttekintése és értékelése a fenntarthatóság szempontjából. NFFT Múhelytanulmányok, 1., KSH Népességtudományi Kutató Intézet, Budapest.

Csalad.hu (2017): Ösztönzi a gyermekvállalást a CSOK. Csalad.hu, http://csalad.hu/2017/02/21/osztonzia-gyermekvallalast-a-csok/\#more-24031 (Letöltés: 2017. március 4.).

Darvas Ágnes - Mózer Péter (2004): Kit támogassunk? Esély, 16. évf., 6. sz., 64-99.

Giday András (2011): Lakáscélú adókedvezményt a fiatalabbaknak. Pénzügyi Szemle, 56. évf., 1. sz., 16-25.

Giday András (2012): Életciklus-szemlélet és a társadalombiztosítás bevételei. Polgári Szemle, 8. évf., 3-6. sz. Kapitány Balázs - Spéder Zsolt (2015): Gyermekvállalás. In: Demográfiai portré 2015. Szerk. Monostori Judit, Ôri Péter, Spéder Zsolt, KSH NKI, Budapest, 41-56.

Központi Statisztikai Hivatal, www.ksh.hu (Letöltés: 2017. május 2.).

NGM (2012): Nagy reformkönyv. Nemzetgazdasági Minisztérium, Budapest.

Spéder Zsolt (2014): Demográfiai folyamatok: születések, halálozások, korösszetétel. In: Társadalmi Riport 2014. Szerk. Kolosi Tamás, Tóth István György, Tárki, Budapest, 63-82. 